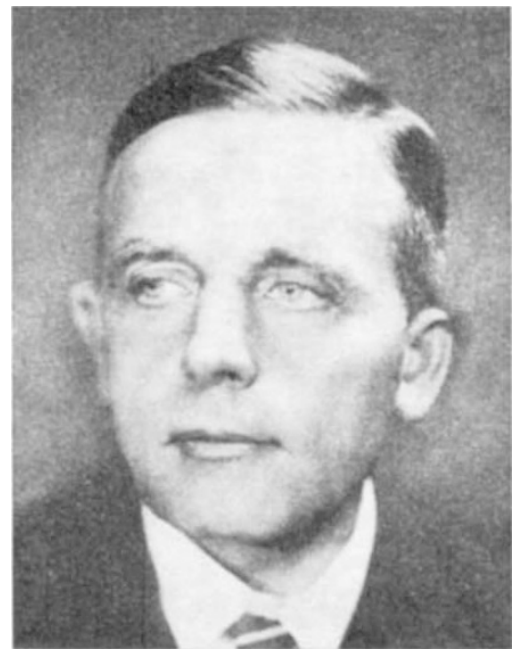

\section{Professor Otto Warburg}

Otto Warburg died on August 1 in his eighty-seventh year, after a short illness, having remained active in research until almost the end. He is universally acknowledged as the greatest biochemist of this century, even though not every conclusion which he drew from his experiments proved acceptable to the scientific community.

Warburg obtained his $\mathrm{PhD}$ in chemistry in 1906 and qualified in medicine in 1911. His main teachers were Emil Fischer, van 't Hoff, Nernst and his father Emil Warburg - the most eminent chemists and physicists of their generation. His genius was recognized early and at the age of thirty, in 1913, he was appointed to a permanent research post in Berlin by the Kaiser Wilhelm Gesellschaft (renamed in 1948 Max-Planck-Gesellschaft). He held this position until his death. The sixty-five year period over which his research extended was interrupted only by war service as a cavalry officer from 19141918 and by the period of confusion following the conquest and occupation of Berlin at the end of the Second World War.

His philosophy was, in his own words: "a scientist must have the courage to tackle the great unsolved problems of his time, and solutions have to be forced by carrying out numerous experiments without much critical hesitation". He applied this to his main research theme, the elucidation of the energy-transforming mechanisms in living organisms. His early work dealt with the study of cell respiration, and he discovered that the respiratory activity of liver is associated with insoluble particles ("grana") which were identified by Claude thirty years later as mitochondria, structures long known to histologists. In 1923 he discovered the high rate of lactic acid formation by cancer tissue and came to the conclusion that the capacity to obtain energy from a lactic acid fermentation, and to grow at the expense of this fermentation, is a major biochemical characteristic of cancer cells. In 1927 the Nobel Committee considered this discovery of sufficient merit for the award of a Nobel Prize. The committee proposed the division of the Prize between Warburg and Fibiger, who had discovered the development of stomach eancer in rats infected with the parasitic worm Spiroptera. The faculty decided, however, to give Fibiger the undivided prize. The subsequent evaluation of Fibiger's work cast grave doubts on the wisdom of this decision, because Spiroptera infection is only one among mant irritative stimuli which can cause cancer.

In the later 1920s Warburg, using ingenious and entirely novel techniques, identified an iron porphyrin as the catalyst responsible for the utilization of oxygen in living cells. For this discovery he was awarded the Nobel Prize in 1931. A few years later he identified flavine mononucleotide and flavine-adenine dinucleotide as prosthetic groups of catalysts of biological oxidations, and he elucidated their mechanism of action. Connected with this work was the discovery of nicotinamide as the main constituent of the coenzymes of dehydrogenasus. In 1944 the Nobel Committee, on account of this work, found Warburg again worthy of a Nobel Prize, but because of Hitler's embargo (he forbado Germans to accept a Prize) the committce did not proceed.

At various times between 1919 and 1970 he was keenly interestcd in the energetics of photosynthesis, the process on which all life ultimately depends. His main objective was to measure the quantum yield of photosynthesis. $\mathrm{He}$ devised conditions under which one molecule of $\mathrm{O}_{2}$ was released for each quantum of light absorbed by the active chlorophyll. He adhered to the old view that the $\mathrm{O}_{2}$ was directly derived from $\mathrm{CO}_{2}$ while the great majority of biochemists have come to the conclusion that the precursor of $\mathrm{O}_{2}$ is water.

Warburg was a pioneer in biochemical methodology. All his great discoveries rested on the creation of new tools of investigation. The manometric methods for the study of cell metabolism, the modern spectrophotometric methods, numerous microanalytical methods, as well as the procedures used for the isolation of cell constituents and the crystallization of enzymes, sprang from his work. He was also a master of scientific prose; his style was distinguished by an economy of words, by clarity and by strict scientific logic.

Warburg was a striking and fascinating person; he was always friendly, helpful and particularly generous with those genuinely interested in his field of research. Many pieces of research which he initiated and to which he contributed a great deal were published without his name, except in an acknowledgement by the author. $\mathrm{He}$ was widely read and well informed in many fields, and his conversation was straightforward, original, penetrating and often had a humorous and highly amusing flavour. The direct look from his bright blue eyos was both engaging and charming; but when it came to scientific argument he was a very forthright fighter for what he regarded as the truth. He crossed swords with many of the leading authorities of his time-Willstätter, Wieland, Keilin among them-and his style in controversy was often scathing and sarcastic. He was motivated by the belief that it was dangerous not to contradict erroneous criticisms.

The many honours bestowed upon Warburg include, apart from the Nobel Prize, Foreign. Membership of the Royal Society (1934) and an honorary doctorate of Oxford University (1965). 